\title{
ANALISIS WACANA KRITIS BAHASA DAN STRATEGI MEDIA \\ SOSIAL CAKRA ABHIPRAYA RESPONSIF DALAM HABITUS
}

Oleh

\author{
Nadira Maurizka Kuputri \\ Sekolah Pascasarjana Universitas Gadjah Mada \\ D.I Yogyakarta, 55281 \\ nadiramaurizka@mail.ugm.ac.id
}

\begin{abstract}
The pandemic caused by Coronavirus Disease (COVID-19) has an impact on all levels of society in Indonesia. The people who are below the poverty line are no exception. The government's call for physical distancing by stopping many sectors of the economy, further worsening the welfare of the underprivileged. One of nongovernmental social organization that was launched on its Instagram page, helping a lot of those in distress, is the Chakra Abhipraya Responsif. In carrying out its activities, the Cakra Abhipraya Responsif is assisted by many parties which makes it easier for them to reach more targets with maximum results. This research tries to look at the communication strategy launched by the Cakra Abhipraya Responsif and their fundraising program through the language they use on their Instagram page. Using Fairclough's critical discourse analysis, the text is analyzed through three components, namely text, discourse practice, and socio-cultural practice. Then by discussing Bourdieu's theory of Habitus and looking far behind the scenes, it can be concluded that social capital in the form of the background/relations of the Cakra Abhipraya Responsif volunteers' influences a lot in the implementation of their activities. Although information about social organizations is quite minimal on the internet. The Cakra Abhipraya Responsif communication strategy uses a caption writing style that flicks the audience by focusing their fundraising on communities whose economies have indeed been in decline long before the existence of this pandemic.
\end{abstract}

Key words: COVID-19, communication strategy, critical discourse analysis, social capital, habitus 
ANALISIS WACANA KRITIS BAHASA DAN STRATEGI MEDIA

SOSIAL CAKRA ABHIPRAYA RESPONSIF DALAM HABITUS

PENDAHULUAN

Kemunculan virus baru menurunkan omset penjualan para

mengubah kehidupan masyarakat pedagang kaki lima. COVID-19 juga dunia, tidak terkecuali Indonesia. berimbas pada perekonomian COVID-19 (Coronavirus Disease) Indonesia yang diakibatkan yang disebabkan oleh SARS-COV2 menurunnya konsumsi rumah tangga. ditetapkan oleh WHO sebagai Pertumbuhan ekonomi Indonesia pun penyakit novel coronavirus pada terancam bisa minus 0,4 persen, tanggal 12 Februari 2020. Berawal dengan sektor UMKM yang paling dari Kota Wuhan, Provinsi Hubei, pertama terdampak meskipun China (sejak Desember 2019), kebijakan untuk memberikan stimulus penambahan jumlah kasus COVID-19 kepada masyarakat sudah dilakukan. di luar Wuhan terjadi cukup cepat (sumber:https://www.voaindonesia.co (Tim Kerja Kemendagri, 2020: 2). Di M/a/menkeu-dampak-covid-19-

Indonesia sendiri kasus terkonfirmasi pertumbuhan-ekonomi-indonesiaCOVID-19 sudah mencapai $7135 \quad \underline{\text { 2020-bisa-minus-0-4- }}$ orang (sumber: covid19.go.id). persen/5355838.html). Dilansir oleh Himbauan pemerintah untuk berdiam VOA Indonesia juga (2/4/2020), Sri diri di rumah masih belum diindahkan Mulyani mengatakan bahwa banyak warga di Indonesia. Bukan Indonesia harus memusatkan karena jenuh di rumah, namun perhatian kepada kesehatan dan terdapat banyak tanggungjawab yang masalah kemanusiaan terlebih dahulu. harus dilakukan oleh banyak orang di Dan kemudian berfokus untuk luar rumah. Pertokoan tutup, pasar menjadmin kondisi masyarakat 
ANALISIS WACANA KRITIS BAHASA DAN STRATEGI MEDIA

SOSIAL CAKRA ABHIPRAYA RESPONSIF DALAM HABITUS

terbawah dan melindungi sektor selama physical distancing

ekonomi mereka.

Meskipun begitu, masih sulit rasanya untuk bangkit dari dampak COVID-19 ini bagi masyarakat minoritas dan kelas bawah. Bantuan banyak dilakukan oleh para selebgram seperti Rachel Vennya, Atta Halilintar, Arief Muhammad, dan masih banyak lagi. Rachel Vennya yang memfokuskan donasinya untuk pengadaan APD (alat pelindung diri) dan perlengkapan medis untuk tenaga kesehatan di berbagai rumah sakit, cukup membatu mereka yang membutuhkan ketika pemerintah belum mampu menjangkau mereka semua. Serupa dengan donatur lain yang menyalurkan dana mereka pada hal tersebut. Pengemudi ojek online juga menjadi sorotan karena banyak membantu pendistribusian barang dan pemesanan makanan ke rumah-rumah berlangsung. Namun banyak juga yang mengeluhkan hal tersebut. Mengutip money.kompas.com (15/04), Pengamat Transportasi Djoko Setijowarno menilai jika pemerintah saat ini hanya terfokus pada pemberian insentif kepada pengemudi ojek online, Djoko Setijowarno berpendapat bahwa masih banyak pelaku usaha lainnya yang merugi akibat pandemi ini. Dengan perkonomian Indonesia yang cukup terpuruk, membiayai semua lapisan masyarakat rasanya cukup berat. Sulit bagi semua orang untuk mengindahkan himbauan pemerintah untuk tetap berada di rumah selama pandemi ini karena masih ada perut yang harus diisi, masih ada cicilan yang harus dilunasi, dan masih ada tanggungjawab yang harus ditepati.

Keberadaan orang baik di tengah wabah ini menjadi sebuah 
ANALISIS WACANA KRITIS BAHASA DAN STRATEGI MEDIA

SOSIAL CAKRA ABHIPRAYA RESPONSIF DALAM HABITUS

angin segar bagi semua orang sansekerta sebagai "cahaya Harapan terutama bagi mereka yang yang Cekatan”, Cakra Abhipraya membutuhkan. Salah satunya Responsif berprinsip bahwa organisasi yang bernama Cakra perbedaan bukan alasan untuk tidak Abhipraya Responsif, yang aktif saling membagaiakan, seperti yang membantu menolong masyarakat tercantum pada Instagram mereka. kurang mampu dan penyandang Tujuan mereka sebagai organisasi disabilitas dengan menggalang dana gerakan sosial berusaha untuk melalui laman membantu siapapun yang kitabisa.com/campaign/sterilisasicovi membutuhkan mereka, terutama d19. Mereka juga bekerja sama kaum minoritas yang tidak semua bisa dengan Dishub Provinsi DKI Jakarta dijangkau oleh pemerintah. dalam melakukan sterilisasi kantor Dalam setiap kegiatannya, Dinas Perhubungan DKI Jakarta dan Cakra Abhipraya Responsif selalu sterilisasi halte transjakarta koridor 1 mengunggahnya ke media sosial Blok M - Kota (sumber: Instagram Instagram (@cakraabhipraya). @dishubdkijakarta) sebagai bentuk Kepada seluruh pengikutnya di CSR (Corporate Social Instagram, mereka 'mengabarkan' Responsibility). Cakra Abhipraya apa kegiatan mereka atau apa yang Responsif merupakan organisasi mereka lakukan atas dasar kerjasama sosial yang memiliki misi untuk dengan berbagai pihak atau dengan menghapus segala kesedihan menjadi melalui donasi yang mereka kebahagiaan, begitu motto mereka. kumpulkan melalui kitabisa.com. Memiliki arti nama dalam bahasa melalui caption yang disisipkan pada 
ANALISIS WACANA KRITIS BAHASA DAN STRATEGI MEDIA

SOSIAL CAKRA ABHIPRAYA RESPONSIF DALAM HABITUS

fotonya, Cakra Abhipraya Responsif

memberikan penjelasan kegiatan

mereka. Produksi teks (berupa tulisan

atau gambar) dimanifestasikan

sebagai sesuatu yang tidak kosong.

Cakra Abhipraya Responsif memiliki

rekam jejak yang cukup brilian

dengan sederet kerjasama dengan

beberapa institusi pemerintahannya.

Tentu apa yang menjadi prestasi dan

budaya dalam organisasi Cakra

Abhipraya Responsif tidak semata-

mata muncul begitu saja. oleh karena

itu penelitian ini berusaha melihat

bagaimana Cakra Abhipraya

Responsif bisa mencapai hal tersebut

dilihat dari teks yang digunakan

dalam Instagram mereka

(@cakraabhipraya).

\section{METODE PENELITIAN}

Penelitian ini menggunakan metode penelitian kualitatif dengan mengambil data dari unggahan Cakra Abhipraya Responsif di Instagram yang terkait dengan penanganan COVID-19 oleh mereka. Beberapa diantaranya adalah unggahan pada tanggal 8 April 2020 yang memuat kegiatan mereka yang bekerjasama dengan@@tni_angkatan_darat, @dishubdkijakarta dan@dinsos_dki; kemudian unggahan pada tanggal 15 April 2020 yang berisi poster (slide pertama) berisi tulisan 'informasi' beserta tiga foto masyrakat yang menjadi target uluran tangan Cakra Abhipraya Responsif.

Pisau analisis yang digunakan dalam penelitian ini adalah analisis wacana kritis Norman Fairclough. Fairclough menggunakan analisis ini karena melalui analisis yang befokus pada linguistik, Fairclough memandang semua "peristiwa" diskursif apapun sebagai sepotong teks dan menyatukan pemikiran sosial dan politik yang relevan dengan wacana dan bahasa (Fairclough: 
ANALISIS WACANA KRITIS BAHASA DAN STRATEGI MEDIA

SOSIAL CAKRA ABHIPRAYA RESPONSIF DALAM HABITUS

1992: 62), teks kemudian dianalisis para pengikutnya di Instagram.

melalui tiga komponen yaitu teks, Bahwasanya teori itu menyatakan

discourse practice, dan socio-cultural kalau habitus membentuk cara agen

practice ( Fairclough: 1993: 8-9). berpikir dalam menjalankan

Teks tidak pernah netral, sehingga strateginya dan mendapatkan modal

analisis ini mencoba melihat ketidak- agar bisa memenuhi kepentingannya

netralan itu dengan paradigma sebagai organisasi sosial.

kritisnya. Dalam teorinya, Fairclough Pierre Felic Bourdieu

merumuskan konsep wacana dengan merupakan salah seorang pemikir

menggabungkan beberapa tradisi Prancis yang terkenal sebagai

yaitu linguistik, interpretatif, dan sosiolog dan antropolog. Karyanya

sosiologi. Sehingga wacana ini mencakup bahasan mengenai

disebut sebagai model perubahan etnografi dan seni, sastra, pendidikan, sosial.

Hasil dari penggunaan analisis

tersebut kemudian diamati melalui

kacamata teori sosiologi yang

membahas pemaduan antara agen dan

struktur, yaitu teori yang dikenal

sebagai teori Habitus oleh Pierre

Kabylie dan Collo, Aljazair. Melihat

Bourdieu (Krisdinanto, 2014). Dari

keterbatasan yang dimiliki

teori Habitus, penelitian ini berusaha

strukturalisme, Bourdieu mulai

melihat distribusi teks yang dilakukan

merumuskan teori Habitus untuk

Cakra Abhipraya Responsif kepada

mengatasi kesulitan dikotomi seperti 
ANALISIS WACANA KRITIS BAHASA DAN STRATEGI MEDIA

SOSIAL CAKRA ABHIPRAYA RESPONSIF DALAM HABITUS

individu dan masyarakat, kebebasan

dan tanggung jawab, subyektivisme

dan obyektivisme (Krisdinanto:

2014).

\section{HASIL DAN PEMBAHASAN}

Melalui unggahan tersebut analisis

teksnya adalah sebagai berikut:

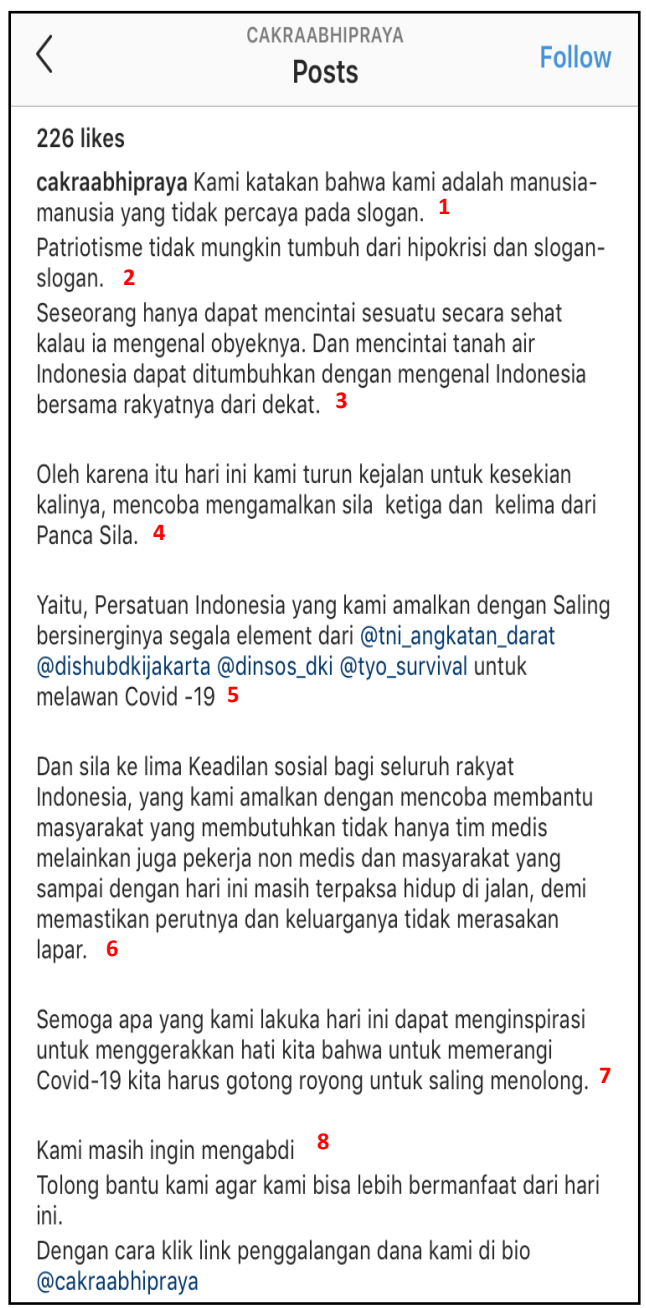

Gambar 1. Unggahan tanggal 8 April 2020

Sumber: diolah dari akun Instagram
1 : "kami" menunjukkan posisi

Cakra Abhipraya Responsif, bahwa mereka tidak percaya dengan slogan. Slogan adalah kalimat yang relatif pendek yang umunya menarik, mencolok, dan mudah untuk diingat yang digunakan untuk menyampaikan informasi (yuksinau.com). Slogan yang dimaksud Cakra Abhipraya Responsif adalah kata-kata pendek yang singkat dan tidak terlalu bermakna.

2 : Cakra Abhipraya Responsif berusaha menempatkan dirinya bahwa mereka merupakan organisasi yang patriotik. Patriotik adalah sifat cinta tanah air (KBBI), oleh karena itu mereka tidak semerta-merta mudah percaya dengan slogan yang singkat, pendek, dan sekilas.

3 : sifat patriotik mereka ditegaskan lagi dengan kalimat "mencintai tanah air Indonesia dapat ditumbuhkan dengan mengenal Indonesia bersama 
ANALISIS WACANA KRITIS BAHASA DAN STRATEGI MEDIA

SOSIAL CAKRA ABHIPRAYA RESPONSIF DALAM HABITUS

rakyatnya dari dekat.”. Kata perusahaan BUMN, seperti Satgas

"mengenal" dapat dikaitkan dengan Penanggulangan Bencana Alam

orang-orang yang menjadi target (Gulbencal) oleh Divif 3 Kostrad bantuan Cakra Abhipraya Responsif. pada kegiatan trauma healing di Palu

4 : kalimat "sekian kalinya" (sumber:https://mercusuar.web.id/trau

mengindikasi bahwa mereka sudah ma-healing-ala-satgas-yonarmed/).

sering melakukan kegiatan charity ini. Kemudian ASABRI dalam

Mereka berupaya mengamalkan "sila memperingati Hari Tuna Rungu

ketiga" sebagai bentuk Internasional, mengajak anak-anak

patriotismenya. Pancasila sila ke-3 disabilitas dari SLB 08 Marunda

berbunyi Persatuan Indonesia ～（sumber:

5 :yang kemudian diperjelas pada http://www.bumn.go.id/asabri/berita/

kalimat nomor 5, persatuan Indonesia 1-ASABRI-Berbagi-Keceriaan-

diimplementasikan dengan ikut kepada-Anak-Anak-Disabilitas-di-

menggandeng beberapa jajaran Hari-Tunarungu). Kegiatan dengan

sebagai mitra mereka diantaranya DISHUB DKI Jakarta juga dilakukan

adalah TNI Angkatan Darat beberapa waktu lalu, yaitu kegiatan

(@tni_angkatan_darat), DISHUB_ penyemprotan disinfektan di seluruh

DKI Jakarta (@dishubdkijakarta), halte Transjakarta Koridor 1, yang

Dinas Sosial DKI Jakarta melalui Instagram DISHUB DKI

(@dinsos_dki), dan Tyo Survival Jakarta merupakan CSR (corporate

(@tyo_survival). social responsibility). Juga Tyo

Cakra Abhipraya Responsif telah Survival yang juga ikut menjadi

beberapa kali bekerja sama dengan relawan dalam penyemprotan 
ANALISIS WACANA KRITIS BAHASA DAN STRATEGI MEDIA

SOSIAL CAKRA ABHIPRAYA RESPONSIF DALAM HABITUS

disinfektan yang bekerja sama dengan

DISHUB DKI Jakarta. Tyo Survival

merupakan mantan host Jejak

Petualang Survival di Trans7

(Wikipedia: Jejak Petualang). Dengan

nama asli Herna Prasetyo, Tyo kini

berfokus pada kegiatan alam

(berdasarkan

unggahan

Instagramnya). Dengan pengikut di

Instagram sebanyak 74ribu dan 346rb

subscribers di Youtube, keikutsertaan

Tyo dalam kegiatan sosial bersama

Cakra Abhipraya Responsif cukup

menarik perhatian audiensnya.

6: dalam mengimplementasikan "Sila

ke lima Keadilan Sosial Bagi Seluruh

Rayat Indonesia" Cakra Abhipraya

Responsif dalam membantu

'masyarakat yang membutuhkan'

menegaskan "tidak hanya tim medis".

Mengindikasikan bahwa sumber

bantuan yang selama ini beredar

dalam menanggulangi COVID-19

kebanyakan berfokus pada tenaga medis berupa APD, surgical mask, dll, dan membuat orang-orang lupa bahwa "pekerja non medis dan masyarakat yang sampai hari ini masih terpaksa hidup di jalan”.

7 : menggunakan kata "kita", Cakra Abhipraya Responsif mengajak para audiens nya untuk ikut gotong royong “memerangi covid-19” dengan-

8 : -merendahkan posisi mereka menggunakan kata "mengabdi". Arti Mengabdi (berdasarkan KBBI) adalah menghamba, berbakti. Bahwa mereka tidak bisa apa-apa tanpa bantuan audiens atau pengikutnya untuk bisa "lebih bermanfaat dari hari ini". Lebih bermanfaat dari kegiatan hari ini, seperti di unggahan tanggal 8 April 2020 ini.

Cakra Abhipraya Responsif menggambarkan dirinya sebagai pihak yang berjiwa patriotik demi membantu negara dengan membantu masyarkat (selain tenaga medis) 
untuk menanggulangi pandemi ini.

Strategi yang mereka lakukan untuk menjadi patriotik adalah dengan mengenal masyarakat Indonesia terlebih dahulu dan kritis dengan mengetahui siapa yang menjadi minoritas dalam pandemi ini.

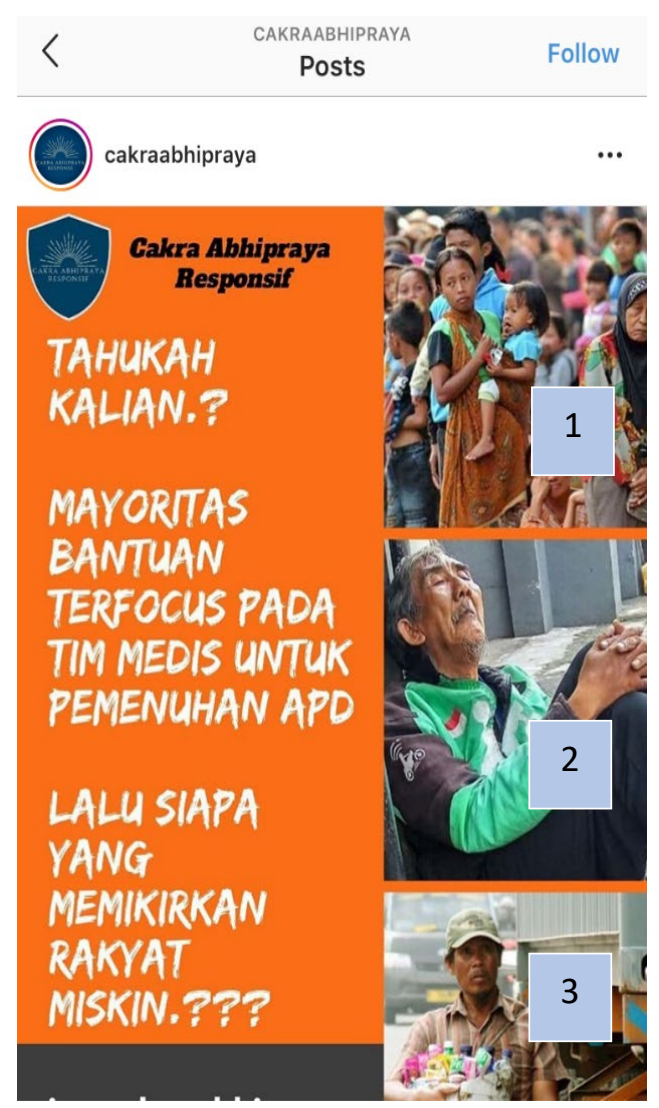

Gambar 2. Unggahan tanggal 15 April 2020

Sumber: diolah dari akun Instagram

Beranjak ke teks kedua yang berupa poster dengan tulisan dan foto.

Tulisan “TAHUKAH KALIAN.?” (1)

Menandakan penyampaian informasi oleh Cakra Abhipraya Responsif. Kemudian mengulang unggahan pada tanggal 8 April 2020 di atas, Cakra Abhipraya Responsif mengingatkan bahwa sampai saat ini (15 April 2020) pembagian bantuan masih terfokus pada tim medis untuk pemenuhan alat pelindung diri. Sehingga masyarakat kurang memperhatikan rakyat miskin yang dilihat melalui gambar pelengkap di bagian samping poster terlihat kesusahan. Gambar pelengkap pertama berupa seorang ibu sedang menggendong anaknya menggunakan kain jarik, dengan latar kerumunan orang yang serupa seperti sedang menantikan sesuatu. Gambar pelengkap kedua merupakan seorang bapak pengemudi ojek online sedang bersandar dengan jaketnya masih terpasang rapi, terlihat raut wajah bapak tersebut dipenuhi emosi sedih dengan kedua tangan memeluk lututnya. Gambar pelengkap ketiga 
berupa seorang bapak pedagang asongan yang lebih muda dari bapak pengemudi ojek online di gambar sebelumnya, sedang berjalan dengan barang jualannya dikawasan yang terlihat seperti terminal.

Dilihat melalui level socio-cultural practice, munculnya pandemi ini mengubah semua rencana tiap individu. Tidak terkecuali masyarakat yang terbatas secara finansial. Melalui poster ini, Cakra Abhipraya Responsif mencoba menyampaikan bahwa hidup mereka (orang yang digambarkan dalam poster) semakin menjadi sulit, sejalan dengan keputusan pemerintah untuk mengadakan PSBB (Pembatasan Sosial Berskala Besar) dan pelarangan mudik, mengambil banyak lapangan kerja mereka. Cakra Abhipraya Responsif dalam unggahan ini memosisikan diri mereka sebagai organisasi sosial yang memihak rakyat miskin terlepas dari pandangan orang lain yang hanya berfokus pada tim medis.

\section{Strategi Cakra Abhipraya} Responsif terlihat dari pemilihan diksi mereka yang berani menggunakan kata-kata yang bersifat sindiran. Kegiatan mereka juga tidak mainmain terjun langsung ke lapangan untuk memberikan disinfektan ke fasilitas publik, tentu dengan bantuan pihak yang berwenang yang saat itu adalah DISHUB DKI Jakarta. Keberhasilan Cakra Abhipraya Responsif dalam menjalankan rangkaian kegiatannya tidak muncul begitu saja. Sumber daya manusia Cakra Abhipraya Responsif bisa menjadi pendukung yang sangat berpengaruh. Mengambil beberapa informasi dari Instagram @cakraabhipraya, relawan yang ikut serta memiliki cukup banyak pengikut di media sosialnya, membuat kegiatan Cakra Abhipraya Responsif dapat 
lebih cepat diketahui orang banyak dan hal ini bisa menguntungkan mereka dalam penggalangan dana yang biasa mereka lakukan melalui platform KitaBisa dengan akun Putro Anugrah Lindu, sebagai ketua Cakra Abhipraya Responsif (berdasarkan berita

\section{https://mercusuar.web.id/trauma-}

healing-ala-satgas-yonarmed/).

Melihat hal tersebut, dapat ditelurusi besar nya relasi yang mereka miliki sebagai organisasi sosial kemungkinan besar didapat dari relasi yang dimiliki para relawan Cakra Abhipraya Responsif.

\section{Teori Habitus dalam Melihat}

Strategi Cakra Abhipraya

\section{Responsif}

Dalam teori Habitus, Bourdieu mengatakan bahwa agen (individu) akan beradaptasi dan bereaksi dengan cara yang sama (sesuai habitusnya yang terbentuk) dalam menghadapi tuntutan-tuntutan dalam dunia sosial tempat ia hidup. Ia akan mengembangkan strategi-strategi dan hal itu berkat habitusnya (Krisdinanto: 2014). Strategi yang mereka lakukan bertujuan untuk meraih keuntungan berdasarkan kepentingan mereka. Kepentingan merupakan sesuatu yang mereka yakini, yang dalam hal ini berupa keberhasilan kegiatan dan pengembangan relasi dan mitra demi keberhasilan kegiatan tersebut. Bourdieu juga mengatakan jika seseorang menentukan strategi berdasarkan arena mereka. Cakra Abhipraya Responsif menggunakan strategi seperti yang dibahas di atas karena mereka yakin telah memiliki relasi dan dukungan sejauh ini dari pihak yang berwenang. Cakra Abhipraya Responsif memperoleh hak mereka untuk berkreasi dalam strateginya melalui posisi-posisi yang 
ANALISIS WACANA KRITIS BAHASA DAN STRATEGI MEDIA

SOSIAL CAKRA ABHIPRAYA RESPONSIF DALAM HABITUS

terdapat dalam arena. Strategi Bourdieu menggambarkan modal berperan sebagai cara agen untuk sebagai sumber daya sosial bagi agen mempertahankan posisi mereka dalam untuk memperoleh manfaat arena permainan untuk mendapatkan (keuntungan). Cakra Abhipraya modal.

Responsif kini berada di arena yang Modal yang coba diperoleh cukup memiliki banyak relasi dan Cakra Abhipraya Responsif hubungan sosial dengan mitra yang merupakan modal sosial atau Le terpercaya seperti perusahaanCapital Social yang mengukur semua perusahaan BUMN. Arena yang sumber daya yang berkaitan dengan mereka tempati sekarang merupakan kepemilikan jaringan sosial dari akumulasi dari modal sosial yang semua relasi dan semua orang yang mereka miliki dan hal tersebut dapat dikenal. Hakikatnya, modal sosial terwujud dengan berdasarkan habitus merupakan hubungan sosial yang ada para agen relawan Cakra Abhipraya di masyarakat (yang dalam hal ini Responsif.

merupakan lingkungan di sekitar Cakra Abhipraya Responsif) yang mencerminkan hasil interaksi sosial sehingga terjalin pola kerjasama, menciptakan jaringan dan pertukaran sosial, dan saling percaya (Bourdieu, 1980. Dalam Krisdinanto, 2014). Modal ini menentukan posisi Cakra Abhipraya Responsif dalam arenanya.

\section{KESIMPULAN}

Hasil penelitian mengenai penggunaan bahasa untuk melihat strategi Cakra Abhipraya Responsif dalam menyebarkan kegiatannya di media sosial merupakan hasil dari habitus para relawan Cakra Abhipraya Responsif. Tidak banyak organisasi sosial yang dapat langsung 
ANALISIS WACANA KRITIS BAHASA DAN STRATEGI MEDIA

SOSIAL CAKRA ABHIPRAYA RESPONSIF DALAM HABITUS

menarik perhatian perusahaan- perekonomiannya memang sudah

perusahaan BUMN untuk ikut terpuruk jauh sebelum adanya

membantu dan bekerjasama dengan pandemi ini.

mereka dan bersama mewujudkan Keterbatasan dalam penelitian

tujuan mereka. Melalui telusuran dari ini adalah, informasi mengenai Cakra

dimensi discourse practice didapati Abhipraya Responsif di internet

bahwa Cakra Abhipraya Responsif cukup minim. Di luar dari berita-

yang baru beroperasi sekitar 2 tahun berita terkait Cakra Abhipraya

ini (dilihat dari unggahan pertama Responsif yang bekerjasama dengan

Instagram tanggal 19 Oktober 2018) mitra mereka. Halaman Facebook

terbilang cukup baru dalam mereka hanya memuat sedikit

menjalankan organisasi sosial ini, dan informasi mengenai organsisasi

dengan kemajuan yang didapati mereka. Pendalaman analisis

sekarang, kemajuan mereka cukup mengenai keterkaitan perumusan

pesat. Dengan modal sosial yang strategi Cakra Abhipraya Responsif

mereka miliki, Cakra Abhipraya dengan teori Habitus dari Bourdieu

Responsif merumuskan strategi dapat diperdalam lebih jauh jika

mereka di Instagram untuk mencapai informasi mengenai relawan dan

tujuan mereka dalam mengatasi Cakra Abhipraya Responsif lebih

COVID-19 dari sisi mereka. Seperti terbuka dan mudah diakses di Internet

menggunakan gaya penulisan caption atau media sosial mereka.

yang menyentil audiens dengan

memfokuskan penggalangan dana

mereka bagi masyarakat yang 
ANALISIS WACANA KRITIS BAHASA DAN STRATEGI MEDIA

SOSIAL CAKRA ABHIPRAYA RESPONSIF DALAM HABITUS

\section{DAFTAR PUSTAKA}

Adib, M. 2011. Agen dan Struktur dalam Pandangan Piere Bourdieu. BioKultur, 1(2), 91-110.

Cakra Abhipraya Responsif. 2020. Instagram Page. @cakraabhipraya. https://www.instagram.com/cakra abhipraya/. Diambil 21 April 2020

DISHUB Provinsi DKI Jakarta. 2020. Instagram Page. (a)dishubdkijakarta.

https://www.instagram.com/dishu bdkijakarta/. Diakses pada 21 April 2020.

Fairclough, N. (1993). Discourse and Social Change. Polity Press.

Intan, G. 2020, April 2. Menkeu: Dampak Covid-19, Pertumbuhan Ekonomi Indonesia 2020 bisa Minus 0,4 persen. VOA Indonesia. https://www.voaindonesia.com/a/ menkeu-dampak-covid-19pertumbuhan-ekonomi-indonesia- 2020-bisa-minus-0-4-

persen/5355838.html. Diakses pada 21 April 2020.

Krisdinanto, N. 2014. Pierre Bourdieu, Sang Juru Damai. KANAL, 2(2), 107-206.

PT ASABRI. 2019, Oktober 17. ASABRI Berbagi Keceriaan kepada Anak-Anak Disabilitas di Hari Tunarungu. ASABRI. http://www.bumn.go.id/asabri/ber ita/1-ASABRI-BerbagiKeceriaan-kepada-Anak-AnakDisabilitas-di-Hari-Tunarungu. Diakses pada 23 April 2020.

R. Ramli, R. 2020, April 15. Pemerintah Diminta Tidak Fokus Beri Insentif ke Ojol. Money Kompas.com. https://money.kompas.com/read/2 020/04/15/133234426/pemerintah -diminta-tidak-fokus-beri-insentifke-ojol. Diakses pada 20 April 2020 . 
Redaksi Harian Mercusuar. 2018,

Oktober 17. Trauma Healing Ala

Satgas Yonarmed. Mercusuar.

https://mercusuar.web.id/trauma-

healing-ala-satgas-yonarmed/.

Diakses pada 23 April 2020.

Tim Kerja Kementrian Dalam

Negeri. 2020. Pedoman Umum

Menghadapi Pandemi Covid-19

Bagi Pemerintah Daerah:

Pencegahan, Pengendalian,

Diagnosis, dan Manajemen.

Kemendagri.

https://www.covid19.go.id.

Diakses pada 20 April 2020.

Wikipedia. (t.t.). Jejak Petualang. https://id.wikipedia.org/wiki/Jejak _Petualang. Diakses pada 23 April 2020. 